\title{
PENGEMBANGAN INSTRUMEN PENILAIAN KINERJA KEMAMPUAN INKUIRI PESERTA DIDIK PADA MATA PELAJARAN FISIKA SMA
}

\author{
${ }^{1)}$ Supahar, ${ }^{2)}$ Zubdan Kun Prasetyo \\ ${ }^{1,2)}$ Universitas Negeri Yogyakarta, Universitas Negeri Yogyakarta \\ ${ }^{1)}$ supahar@uny.ac.id, ${ }^{2)}$ zuhdan@uny.ac.id.
}

\begin{abstract}
Abstrak
Penelitian ini bertujuan mengembangkan instrumen penilaian kinerja kemampuan inkuiri mata pelajaran fisika peserta didik SMA. Instrumen terdiri atas empat paket perangkat tes yang masing-masing terdiri atas 30 butir tes termasuk 9 butir bersama yang telah divalidasi oleh ahli pendidikan fisika, ahli fisika, ahli pengukuran, dan praktisi. Instrumen diujicobakan pada 2015 peserta didik. Model respon butir politomus empat kategori digunakan untuk menganalisis data hasil uji coba menurut Partial Credit Model (PCM). Hasil penelitian menunjukkan bahwa, berdasarkan kriteria batas terendah dan tertinggi mean INFIT MNSQ, yaitu 0,77 dan 1,30 butir tes semuanya fit dengan model PCM. Tingkat kesulitan butir-butir tes berada pada rentang antara $-0,83$ sampai $+0,84$ yang berarti butir-butir tes dalam kategori baik karena nilainya di antara $-2,0$ dan $+2,0$. Fungsi informasi total tes relatif tinggi untuk kemampuan antara $-2,5$ sampai $+2,5$. Dengan demikian, instrumen yang dikembangkan dapat digunakan untuk mengukur kemampuan inkuiri mata pelajaran fisika siswa SMA. Hasil pengukuran menunjukkan bahwa kemampuan inkuiri peserta didik pada mata pelajaran fisika SMA di DIY berada di atas kemampuan rata-rata.
\end{abstract}

Kata kunci: kemampuan inkuiri, mata pelajaran fisika SMA, Penilaian kinerja.

\section{DEVELOPING ASSESSMENT INSTRUMENT OF THE PERFORMANCE OF THE INQUIRY ABILITIES IN PHYSICS SUBJECT OF HIGH SCHOOL STUDENTS}

\author{
${ }^{1)}$ Supahar, ${ }^{2)}$ Zubdan Kun Prasetyo \\ ${ }^{1,2)}$ Universitas Negeri Yogyakarta, Universitas Negeri Yogyakarta \\ ${ }^{1)}$ supahar@uny.ac.id, ${ }^{2)}$ zuhdan@uny.ac.id.
}

\begin{abstract}
The research was to develop an assessment instrument of performance for the inquiry ability of physic subject of senior high school students. The instrument consisted of four package sets of test and each of the sets consisted of 30 test items, including 9 items that had been validated by the expert of physic education, the expert of physic, the expert of measurement and the practitioner. The instrument was tested to 2,015 learning participants. The fourcategory politomous item response model was implemented for the data analysis of the experiment results according to the Partial Credit Model (PCM). The results of the research showed that based on the criteria of the lowest benchmark and the highest benchmark of mean INFIT MNSQ, was 0.77 and 1.30, all of the test items had been fit with the PCM model. The difficulty level of the test items was between -0.83 and $+0,84$ which implied that the test items belonged to the good category because the value of the test items was between -2.0 and +2.0 . The informative function of the total tests was relatively high for ability between -2.5 to +2.5 . Thereby, the instrument developed can be used for measuring the inquiry ability of the physic subject of the senior high school students. The results of measurement showed that the inquiry ability of the learning participants in physic subject within the senior high schools in DIY was above average.
\end{abstract}

Keywords: inquiry ability, physic subject in senior high schools, performance assessment 


\section{Pendahuluan}

Mata pelajaran fisika di SMA menyajikan berbagai pengalaman belajar untuk memahami konsep, melatih kemampuan inkuiri, dan menggunakan ketrampilan proses sains untuk mempelajari fenomena alam. Salah satu tuntutan dalam rumusan kompetensi dasar (KD) dalam standar isi kurikulum nasional untuk jenjang SMA adalah: (1) melakukan percobaan, dan (2) memahami prinsip-prinsip pengukuran, dan (3) melakukan pengukuran besaran fisika secara langsung dan tidak langsung secara cermat, teliti, dan obyektif. Dengan demikian, untuk mencapai kompetensi dasar mata pelajaran fisika SMA diperlukan kemampuan inkuiri

National Science Education Standards dalam Wenning (2005, p.3) menyatakan bahwa, inkuiri bagi peserta didik sebagai kegiatan peserta didik untuk mengembangkan pengetahuan dan pemahaman tentang ide-ide ilmiah, serta pemahaman bagaimana cara para ilmuwan mempelajari dunia alam. Moyer, et.al. (2007, p.5) mendifinisikan inkuiri sebagai proses-proses sains yang mencerminkan metode saintifik. Bass, et.al. (2009, p.17) mendifinisikan inkuiri sebagai suatu cara ilmuwan melakukan penyelidikan. Dengan demikian, peserta didik di SMA yang terlibat dalam kegiatan inkuiri harus belajar metode saintifik yang meliputi perencanaan, pelaksanaan, dan pelaporan termasuk didalamnya pengkomunikasian hasil penyelidikan.

Chiappetta \& Koballa (2010, p.130) menyebutkan bahwa, kemampuan inkuiri meliputi strategi keterampilan proses sains yang didalamnya termasuk keterampilan membuat model dalam bentuk diagram alir atau membuat model matematika serta keterampilan mengkomunikasikan hasil pengamatan atau percobaan. Proses-proses sains menurut Bryce, et.al. (1990, pp.1-4) terdiri atas aspek: (a) basic skills dan (b) prosess skills. Proses-proses sains menurut Rezba, et.al. (1995, p.1) terdiri atas aspek: (a) basic science process skills, dan (b) integrated science process skills. Proses-proses sains menurut Subali (2009, pp. 581-593) terdiri atas aspek: (a) keterampilan dasar, (b) keterampilan mengolah/memproses, dan (c) keterampilan menginvestigasi. Berdasarkan pendapat para ahli seperti tersebut, maka dapat dirumuskan bahwa proses-proses sains sebagai kemampuan inkuiri (processes science as inquiry) terdiri atas subaspek: (1) perencanaan penyelidikan, (2) pelaksanaan penyelidikan, dan (3) pelaporan hasil penyelidikan. Indikator subaspek perencanaan penyelidikan meliputi: merancang penyelidikan dan menyeleksi prosedur. Indikator subaspek pelaksanaan penyelidikan meliputi kemampuan: melakukan pengamatan, merekam data/ informasi, mengikuti instruksi, melakukan pengukuran, memanipulasi gerakan, mengimplementasikan prosedur/teknik/penggunaan peralatan, dan melaksanakan penyelidikan. Indikator subaspek pelaporan terdiri atas subsubaspek: membuat prediksi, membuat inferensi, melaporkan hasil penyelidikan, dan memaparkan hasil penyelidikan. Secara ringkas inkuiri melalui proses-proses sains disajikan pada Gambar 1.

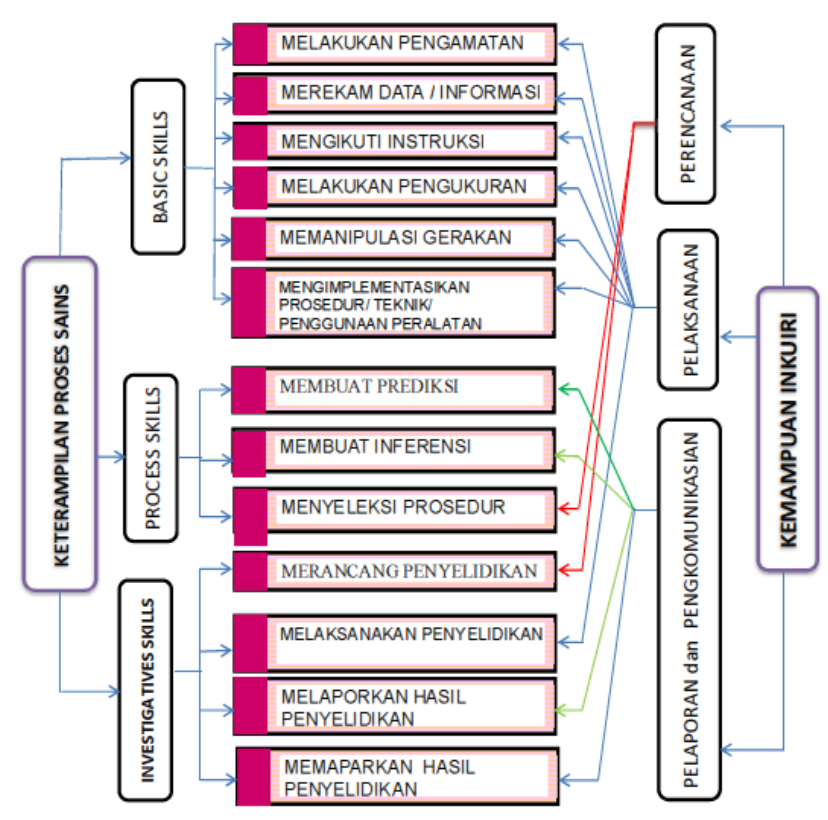

Gambar 1. Kemampuan Inkuiri melalui strategi keterampilan proses sains.

Penilaian hasil belajar peserta didik perlu dilakukan secara berkesinambungan agar perkembangan hasil belajarnya terpantau. Sistem penilaian di sekolah sudah diundangkan dalam bentuk Peraturan Menteri Pendidikan dan Kebudayaan Nomor 104 
Tahun 2014. Format penilaian dapat berupa tes tertulis, observasi, tes praktik, dan penugasan perseorangan atau kelompok. Glencoe science (t.t.,p.3) menyatakan bahwa, penilaian kinerja memberikan jendela pada seberapa baik siswa menggunakan satu dan lebih unsur literasi. Penilaian kemampuan inkuiri mata pelajaran fisika peserta didik SMA dapat diukur menggunakan penilaian kinerja.

Penilaian kinerja idealnya dilakukan melalui metode direct observation yang dapat dijadikan sebagai benchmark. Metode alternatif lain, sebagai pengganti observasi langsung adalah melalui metode: notebooks, simulasi komputer, dan paper and pencil test (RuizPrimo \& Shavelson: 1996, pp.1047-1050). Dalam penelitian ini penilaian kinerja dilakukan menggunakan format penilaian kinerja melalui paper and pencil test.

Penilaian kinerja melalui paper and pencil test dapat dilakukan sebelum dan sesudah pembelajaran. Tujuannya untuk memastikan bahwa peserta didik telah memiliki informasi dan pengetahuan yang cukup akurat sebelum melakukan percobaan dan sebagai strategi untuk mengungkap hasil keterlibatan para peserta didik dalam belajar.

Penilaian kinerja melalui paper and pencil test juga digunakan untuk mengungkap kemampuan peserta didik tentang pengetahuan dan pemahaman proses-proses sains dan prosedur-prosedur inkuiri (Bass et. al., 2009, p. 173). Pengujian kinerja dilakukan pada kondisi tertentu yang merupakan tiruan dari keadaan yang sesungguhnya. Testi diminta untuk menampilkan kemampuannya dalam mengerjakan suatu tugas. Respon/jawaban peserta didik dinilai dan dibandingkan dengan kriteria yang telah ditetapkan dalam rubrik.

Hasil penilaian kinerja bidang sains dalam program for International Student Assessment (PISA), diketahui bahwa skor rata-rata kinerja bidang sains mendudukkan peserta didik Indonesia berada di ranking ke-50 dari 57 negara (Chiappetta \& Koballa, 2010, pp. 22-24). Keadaan ini menggambarkan bahwa kemampuan kinerja bidang sains umumnya dan fisika khususnya bagi peserta didik di Indonesia masih rendah dibandingkan negara-negara lainnya. Penilaian kinerja melalui tes kemampuan inkuiri diharapkan dapat untuk mengukur basis pengetahuan, kemampuan, dan keterampilan inkuiri pada mata pelajaran fisika SMA yang meliputi kemampuan perencanaan, pelaksanaan, dan pelaporan sehingga memberikan gambaran yang lebih lengkap tentang prestasi peserta didik.

Praktik penilaian di sekolah menggunakan metode testing dengan butir berbentuk pilihan ganda masih dominan dipergunakan dalam berbagai keperluan pengujian. Di lain pihak, penilaian kinerja jarang digunakan utamanya untuk pengukuran dalam skala besar. Berdasarkan survei awal pada pelajaran fisika SMA, pembelajaran secara inkuiri telah dilakukan tetapi guru belum melaksanakan penilaian kinerja kemampuan inkuiri karena belum tersedianya instrumen untuk mengukur kinerja tersebut. Oleh karena itu, adanya penelitian untuk mendukungnya perlu dilakukan. Penelitian ini akan menjadi sangat penting artinya bagi kegiatan pembelajaran fisika di SMA agar kemampuan inkuiri peserta didik dapat terukur.

Masalah utama yang akan diungkap dalam penelitian ini adalah bagaimanakah instrumen penilaian kinerja kemampuan inkuiri mata pelajaran fisika SMA pada setiap aspek yang disertai karakteristiknya yang meliputi kemampuan perencanaan, pelaksanaan, dan pelaporan?

Sejalan dengan rumusan masalah yang akan diselesaikan, maka tujuan penelitian ini adalah: (1) menghasilkan instrumen pengukur kemampuan inkuiri dalam mata pelajaran fisika di SMA, dan (2) mendapatkan karakteristik instrumen penilaian kinerja kemampuan inkuiri yang meliputi kemampuan perencanaan, pelaksanaan, dan pelaporan.

\section{Metode Penelitian}

Penelitian pengembangan instrumen penilaian kinerja kemampuan inkuiri mata pelajaran fisika SMA ini menggunakan pendekatan deskriptif kuantitatif. Model 
pengembangan perangkat tes kemampuan inquiri mata pelajaran fisika SMA di DIY menggunakan modifikasi model menurut Mardapi (2012, p.110) dan Oriondo \& Dalo-Antonio (1984, pp.10-11). Tahapan pengembangan perangkat tes terdiri atas tiga tahap, yakni (1) tahap perencanaan tes, (2) tahap uji coba perangkat tes, dan (3) tahap pengukuran.

Penelitian dilakukan di SMA Negeri di DIY pada bulan Januari sampai dengan Juni 2013. Perencanaan tes yang berupa penyiapan tes, validasi, dan perakitan tes dilakukan pada bulan Januari-Maret 2013. Uji coba dilakukan di sepuluh SMA Negeri di DIY pada bulan April sampai dengan Mei 2013. Pengukuran dilakukan di tiga belas SMA Negeri di DIY pada bulan MeiJuni 2013. Pemilihan sekolah sebagai lokasi penelitian didasarkan pada ranking ujian nasional (UN) tahun 2012 yang dipilih secara purposive sampling. Pemilihan SMA Negeri diharapkan dapat mewakili variasi yang besar pada karakteristik peserta didik seperti latar belakang keluarga, budaya, etnik, agama, sosial, dan ekonomi.

Subjek penelitian meliputi seluruh peserta didik SMA kelas X, dan XI-IPA yang hadir di lokasi penelitian pada saat pengujian. Kelas XII-IPA tidak dilibatkan sebagai subjek penelitian karena sedang menghadapi UN tahun 1013. Uji coba perangkat penilaian melibatkan 2015 responden dan tahap pengukuran melibatkan 2383 responden.

Prosedur penelitian meliputi kegiatan: (1) Perencanaan tes meliputi penetapan tujuan tes, penyiapan blue print, penyusunan butir tes dan rubrik, perakitan butir tes, penetapan validitas oleh pakar, revisi, dan perakitan instrumen. (2) Tahap uji coba meliputi penetapan SMA, pelaksanaan ujian, penskoran, analisis butir, revisi butir tes yang belum memenuhi kriteria parameter butir tes yang diinginkan, dan (3) Tahap pengukuran meliputi perakitan tes berdasarkan hasil uji coba, penetapan SMA, pengujian, penskoran, dan interpretasi hasil pengukuran. Secara bagan dapat disajikan seperti Gambar 2.

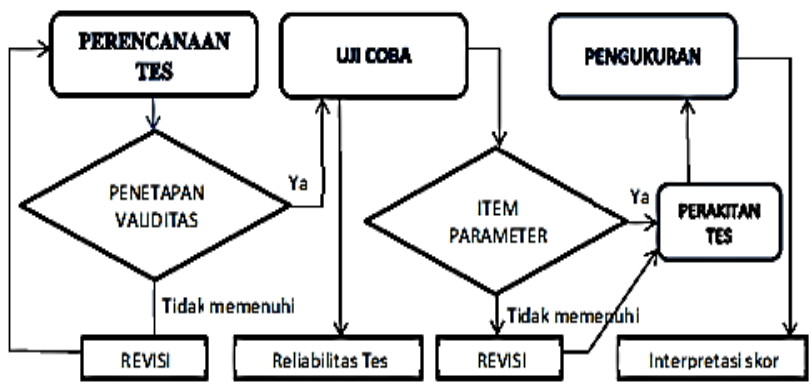

Gambar 2. Skema prosedur penelitian

Data penelitian berupa skor hasil tes kemampuan inkuiri mata pelajaran fisika SMA. Skor hasil tes berupa data politomus empat kategori. Instrumen pengumpul data menggunakan perangkat tes kemampuan inquiri mata pelajaran fisika SMA. Perangkat tes terdiri atas 93 butir soal. Mengingat dalam setiap tatap muka di kelas disediakan waktu selama 90 menit, maka tidak mungkin setiap peserta didik dapat menyelesaikan seluruh butir tes sesuai alokasi waktu yang disediakan. Atas dasar pertimbangan tersebut, rancangan tes dibagi menjadi empat perangkat tes, yaitu perangkat tes berkode A, B, C, dan D. Setiap perangkat tes disusun dengan mempertimbangkan keterwakilan setiap aspek kemampuan inquiri yang akan diukur.

Setiap perangkat tes terdiri atas 30 butir soal termasuk 9 butir soal anchor. Setiap responden hanya diwajibkan mengerjakan satu perangkat tes yang disediakan di bawah pengawasan guru kelas. Keuntungan yang diperoleh dengan desain pengujian seperti ini antara lain, kecurangan dalam mengerjakan soal dapat diminimalkan.

Data respons testi dianalisis menurut partial credit model (PCM) yang merupakan pengembangan dari model Item Response Theory (IRT) 1 parameter of logistic (1-PL). Analisis data meliputi: (1) pengujian goodness of fit item dengan model PCM; (2) penetapan indeks reliabilitas tes; (3) estimasi tingkat kesukaran item; (4) estimasi parameter ability; dan (5) melukiskan kurva fungsi informasi total dan standard error of measurement (SEM).

Pengujian goodness of fit test terhadap PCM ditentukan besaran INFIT Mean of 
Square (Mean INFIT MNSQ) beserta simpangan bakunya. Apabila besarnya nilai rata-rata INFIT MNSQ mendekati 1.0 dengan simpangan baku mendekati 0.0 maka keseluruhan butir tes fit dengan PCM. Penetapan goodness of fit setiap butir terhadap PCM mengikuti kaedah yang ditetapkan oleh Adam \& Khoo (1996, p. 30), bahwa suatu butir fit dengan model bila besarnya nilai INFIT MNSQ pada kisaran 0.7 sampai 1.30. Kisaran nilai INFIT MNSQ tersebut membatasi sebaran skor terkalibrasi dan masih berada pada kurva yang berbentuk Leptokurtic yang mencermin-kan masih dlam kondisi unity.

Pengujian difficulty index menggunakan kriteria menurut Hambleton \& Swaminathan (1985, p. 36), bahwa suatu butir tes dikategorikan sangat sulit jika difficulty index (b) $>+2$ dan dikategorikan sangat mudah jika $b<-2$. Dengan demikian, pada pengembangan tes ini diusahakan butir tes memiliki nilai $-2 \leq b \leq+2$. Penetapan kriteria reliabilitas tes didasarkan pada pendapat Sumadi Suryabrata (2000, p. 40), bahwa hasil testing untuk membuat keputusan tentang individu hendaknya digunakan tes yang koefisien reliabilitasnya sekurang-kurangnya 0,90 . Semakin tinggi koefisien reliabilitas suatu tes, maka kemungkinan kesalahan yang terjadi akan semakin kecil kalau akan membuat keputusan berdasarkan skor yang diperoleh dalam tes.

Hasil pengukuran kemampuan inkuiri disajikan dalam bentuk: (1) distribusi frekuensi ability dalam skala logit, dan (2) tabel persentase kategori level kemampuan.

\section{Hasil Penelitian dan Pembahasan}

Hasil Penelitian

Hasil pengembangan instrumen meliputi rumusan blue print tes, indikator, dan butir-butir penilaian kinerja kemampuan inkuiri. Perumusan blue print tes penilaian kinerja kemampuan inkuiri diharapkan dapat mencerminkan konstruk keilmuan maupun sebagai target pembelajaran fisika SMA. Indikator penilaian kinerja kemampuan inkuiri mata pelajaran fisika SMA dijadikan dasar untuk mengembangkan butir tes. Rumusan blue print tes penilaian kinerja kemampuan inkuiri mata pelajaran fisika SMA dalam penelitian disajikan pada Gambar 3.

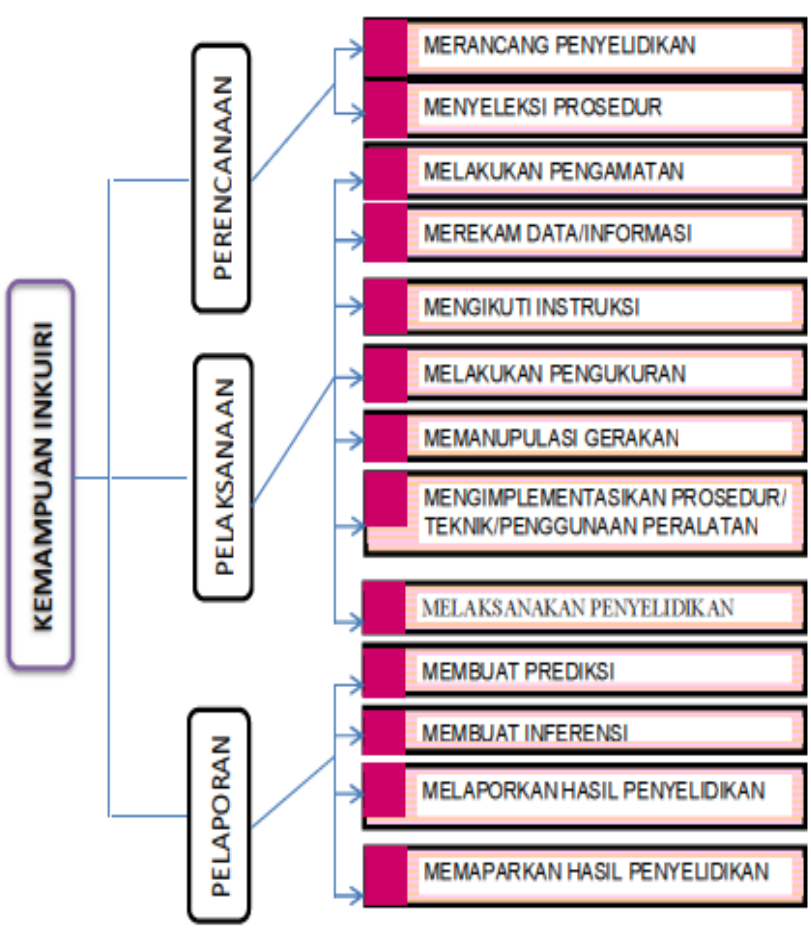

Gambar 3. Blue print tes penilaian kinerja kemampuan inkuiri mata pelajaran fisika SMA.

Indikator aspek perencanaan yang meliputi subaspek merancang penyelidikan disajikan pada Tabel 1, dan menyeleksi prosedur disajikan pada Tabel 2. Indikator aspek pelaksanaan yang meliputi subaspek melakukan pengamatan disajikan pada Tabel 3, merekam data/informasi disajikan pada Tabel 4, mengikuti instruksi disajikan pada Tabel 5, melakukan pengukuran disajikan pada tabel 6, memanipulasi gerakan disajikan pada Tabel 7, mengimplementasikan prosedur/teknik/penggunaan peralatan disajikan pada Tabel 8 , dan melaksanakan penyelidikan disajikan pada Tabel 9 .

Indikator pelaporan yang meliputi subaspek: membuat inferensi disajikan pada Tabel 10, membuat prediksi disajikan pada Tabel 11, melaporkan hasil penyelidikan disajikan pada Tabel 12, dan memaparkan hasil penyelidikan disajikan pada Tabel 13. 
Tabel 1. Merancang Penyelidikan

No.
1. Menetapkan variabel bebas sebagai faktor
perlakuan dalam penyelidikan.
2. Mengidentifikasi hubungan antara variabel
bebas dan variabel gayut dalam suatu
penyelidikan.
3. Mengemukakan latar belakang pentingnya
diperlukan suatu penyelidikan.
4. Merumuskan tujuan penyelidikan.
5. Merumuskan manfaat suatu penyelidikan
6. Merancang pengendalian variabel.
pengganggu (suppressed variabel) menjadi
variabel kendali (Control variabel) dalam
suatu eksperimen.
7. Mengidentifikasi suatu variabel
acak/random dalam suatu penyelidikan
8. Menetapkan hipotesis penelitian dalam
suatu penyelidikan
9. Menetapkan variabel pengukuran dalam
penyelidikan
10. Menetapkan prosedur pengumpulan data
suatu penyelidikan
11. Merancang rangkaian peralatan
penyelidikan.
12. Merancang jenis data yang harus
13. Merancang penyajian data hasil suatu
penyelidikan.
14. Merancang teknik analisis data suatu hasil
penyelidikan.
Men dalam suatu penyelidikan

Tabel 2. Menyeleksi Prosedur

\begin{tabular}{l}
\hline No $\quad$ Indikator \\
\hline 1. Mengantisipasi resiko dan mengadopsi \\
tindakan pencegahan dan prosedur yang \\
tepat dalam melakukan setiap percobaan \\
laboratorium/ penyelidikan praktis. \\
2. Mengidentifikasi suatu prosedur yang \\
sesuai (seperti: pengamatan, pencacahan, \\
pengukuran, pengambilan sampel, \\
pemanasan) atau memilih peralatan yang \\
tepat sesuai . \\
3. Memilih komponen peralatan yang sesuai \\
untuk menghasilkan pengukuran yang \\
teliti/akurat. \\
4. Memilih variabel yang sesuai, \\
mengumpulkan data yang relevan, dan \\
memilih suatu bentuk sajian hasil yang \\
sesuai untuk suatu prosedur penyelidikan \\
yang telah dipilih.
\end{tabular}

Tabel 3. Melakukan Pengamatan

\begin{tabular}{l}
\hline No. Indikator \\
\hline 1. Mengidentifikasi jenis data yang dapat \\
dihimpun dalam melakukan pengamatan \\
dengan atau tanpa alat ukur. \\
2. Mengidentifikasi jenis data yang dapat \\
dihimpun dalam melakukan pengamatan \\
sesuai dengan alat indera yang digunakan. \\
3. Mengidentifikasi objek berdasarkan \\
deskripsinya. \\
4. Mengidentifikasi objek untuk dicocokkan \\
dengan rujukan tertentu \\
(warna/bentuk/fase) \\
5. Mengidentifikasi persamaan/perbedaan \\
antarobjek. \\
6. Mencocokkan suatu objek dengan beragam \\
representasi visualnya. \\
7. Mengidentifikasi situasi berpotensi penuh \\
resiko saat bekerja dilaboratorium dengan \\
yang ada di dalam kehidupan sehari-hari. \\
\hline
\end{tabular}

Tabel 4. Merekam Data

\begin{tabular}{|c|c|}
\hline No. & Indikator \\
\hline $\begin{array}{ll}1 . & 1 \\
1 \\
1\end{array}$ & $\begin{array}{l}\text { Merekam informasi sederhana dengan } \\
\text { merepresentasikannya dalam bermacam } \\
\text { bentuk sesuai dengan klasifikasinya. }\end{array}$ \\
\hline 2. 1 & Membuat suatu ringkasan \\
\hline & Memberi label suatu bagan/ diagram. \\
\hline & Menggambar bentuk sederhana \\
\hline & $\begin{array}{l}\text { Menyusun informasi dalam bentuk table } \\
\text { lengkap dengan judul table. }\end{array}$ \\
\hline 6. 1 & $\begin{array}{l}\text { Melengkapi suatu bagan/carta, grafik, } \\
\text { atau histogram. }\end{array}$ \\
\hline
\end{tabular}

Tabel 5. Mengikuti Instruksi

\begin{tabular}{|c|c|}
\hline No. & Indikator \\
\hline & $\begin{array}{l}\text { Menyelesaikan suatu prosedur } \\
\text { (dengan/tanpa alat) setelah guru } \\
\text { mendemonstrasikannya. }\end{array}$ \\
\hline 2. & $\begin{array}{l}\text { Menyelesaikan suatu prosedur (dengan } \\
\text { atau tanpa alat) menurut perintah yang } \\
\text { disampaikan secara lisan. }\end{array}$ \\
\hline 3. & $\begin{array}{l}\text { Menyelesaikan suatu prosedur } \\
\text { (dengan/tanpa alat) berdasarkan kartu } \\
\text { petunjuk kerja yang seluruhnya/sebagian } \\
\text { besar berisi informasi dalam bentuk } \\
\text { gambar. }\end{array}$ \\
\hline & $\begin{array}{l}\text { Menyelesaikan suatu prosedur } \\
\text { (dengan/tanpa alat) berdasarkan kartu } \\
\text { petunjuk kerja yang seluruhnya/sebagian } \\
\text { besar berisi informasi berupa tulisan. }\end{array}$ \\
\hline
\end{tabular}


Tabel 6. Melakukan Pengukuran

\begin{tabular}{|c|c|}
\hline No. & Indikator \\
\hline 1. & $\begin{array}{l}\text { Menyediakan unit/alat pengukur untuk } \\
\text { melakukan pengukuran }\end{array}$ \\
\hline 2. & $\begin{array}{l}\text { Melakukan pengukuran menggunakan alat ukur } \\
\text { yang skalanya dibaca dengan posisi horizontal. }\end{array}$ \\
\hline 3. & Melakukan pengukuran dengan alat ukur analog. \\
\hline 4. & $\begin{array}{l}\text { Melakukan pengukuran dengan alat yang skalanya } \\
\text { dibaca dengan posisi vertical. }\end{array}$ \\
\hline 5. & Melakukan pengukuran dengan alat ukur digital. \\
\hline 6. & Mengestimasi besaran Fisika secara kasar \\
\hline & $\begin{array}{l}\text { Menggunakan kertas grafik untuk mengestimasi } \\
\text { panjang lintasan/ arah lintasan/ luas penampang } \\
\text { permukaan benda. }\end{array}$ \\
\hline
\end{tabular}

Tabel 7. Memanipulasi Gerakan

\begin{tabular}{l} 
No. Indikator \\
\hline 1. Mendemonstrasikan kendali motorik kasar dalam \\
berbagai cara (misalnya menyalakan alat ukur \\
analog/digital). \\
2. Mendemonstrasikan kendali motorik halus dalam \\
berbagai cara (misalnya mengkalibrasi, \\
merangkai, melengkapi bagan, memasang alat \\
ukur)
\end{tabular}

Tabel 8. Mengimplementasikan Prosedur/teknik/penggunaan Peralatan

No. Indikator

1. Mengidentifikasi peralatan laboratorium yang biasa digunakan.

2. Memilih peralatan laboratorium yang sesuai dengan spesifikasi tugas yang dikerjakan.

3. Mengadopsi prosedur laboratorium dengan meminimalkan resiko / kesalahan.

4. Memindahkan suatu material padat

5. Memindahkan suatu material cair

6. Memindahkan material padat atau cair dengan menggunakan cara tertentu

7. Memisahkan benda menurut ukurannya.

8. Menggunakan alat ukur untuk menghasilkan suatu volume tertentu yang ditetapkan

9. Mencampur sejumlah kecil bahan untuk menghasilkan campuran/ramuan sesuai standar yang ditentukan

10. Menghancurkan material padat menggunakan prosedur/metode tertentu

11. Menjaga keselamatan kerja jika bekerja menggunakan api atau alat yang mudah terbakar

12. Menjaga keselamatan kerja jika bekerja dengan peralatan sumber cahaya

13. Menjaga keselamatan kerja jika bekerja dengan peralatan kaca

14. Merangkai suaturangkaian listrik sederhana sesuai bagan rangkaian yang ditetapkan.
Tabel 9. Melaksanakan Penyelidikan

\begin{tabular}{l}
\hline Indikator \\
\hline Secara simultan melakukan: (1) menyusun \\
rangkaian peralatan penyelidikan/eksperimen \\
sesuai rancangan; (2) mengatur perlakuan dalam \\
eksperimen sesuai rancangan; (3) memanupulasi \\
variabel pengganggu atau variabel asing sesuai \\
rancangan;(4) melakukan pengukuran untuk \\
menghimpun data sesuai rancangan; (5) mencatat \\
seluruh data eksperimen sesuai rancangan; (6) \\
menjaga kesetabilan kondisi lingkungan saat \\
melakukan eksperimen; (7) mengamati dan \\
mencatat data yang menunjukkan penyimpangan \\
bila melakukan eksperimen.
\end{tabular}

Tabel 10. Membuat Inferensi

\begin{tabular}{ll}
\hline No. & \multicolumn{1}{c}{ Indikator } \\
\hline 1. & Membedakan antara hasil observasi dengan \\
rujukannya. \\
2. \\
Membuat generalisasi yang masuk akal \\
berdasar hasil observasi. \\
3. Mengkombinasikan observasi dan informasi \\
yang diberikan untuk merumuskan hipotesis. \\
4. Membuat deduksi dari hipotesis \\
5. Menggunakan hasil observasi untuk \\
mengkomfirmasikan atau membuktikan \\
kesalahan/menyangkal hipotesis yang ada. \\
6. Memodifikasi hipotesis untuk \\
mengakomodasi observasi/penelitian baru \\
\hline
\end{tabular}

Tabel 11. Membuat Prediksi

\begin{tabular}{ll}
\hline \multicolumn{1}{c}{ Indikator } \\
\hline 1. & Memprediksi perubahan kondisi objek. \\
2. & Memprediksi perubahan bentuk objek. \\
3. & Memprediksi perubahan objek dari segi ting- \\
katan/ fase.
\end{tabular}

Tabel 12. Melaporkan Hasil Penyelidikan

\begin{tabular}{ll}
\hline No. & \multicolumn{1}{c}{ Indikator } \\
\hline 1. & Menyajikan hasil suatu penyelidikan dalam \\
bentuk diagram, tabel, ataupun grafik \\
2. Menyajikan kesimpulan data hasil suatu \\
penyelidikan \\
3. Menyajikan pembahasan suatu hasil \\
penyelidikan \\
4. Menetapkan kebenaran hasil penyelidikan \\
5. Menarik kesimpulan umum hasil penyelidikan \\
berdasarkan hasil observasi dan generalisasi \\
data/hasil analisis statistika. \\
6. Menuangkan hasil, pembahasan, dan simpulan \\
suatu penyelidikan dalam laporan secara tertulis \\
\hline
\end{tabular}


Tabel 13. Memaparkan Hasil Penyelidikan

\begin{tabular}{l}
\hline \multicolumn{1}{c}{ Indikator } \\
\hline Memaparkan hasil penyelidikan, pembahasan dan \\
kesimpulan hasil penyelidikan dalam suatu laporan \\
secara lisan dalam suatu seminar/presentasi kelas. \\
\hline
\end{tabular}

Pengembangan butir tes berpedoman rumusan indikator. Setiap rumusan indikator dibuatkan minimal satu butir soal. Perangkat penilaian kemampuan inkuiri mata pelajaran fisika SMA seluruhnya berjumlah 93 butir tes dengan 9 butir tes digunakan sebagai anchor items yang dibagi 4 paket perangkat tes. Tabel 14 menyajikan distribusi butir tes pada setiap paket perangkat tes.

Tabel 14. Distribusi Butir Tes pada Setiap
Perangkat Tes

Hasil Uji Coba

Uji coba instrumen melibatkan 2015 responden yang berasal dari 10 SMA Negeri di DIY. Responden pada kegiatan uji coba meliputi peserta didik kelas $\mathrm{X}$ berjumlah 1100 peserta didik dan kelas XI-IPA berjumlah 915 peserta didik. Pelaksanaan ujian dirancang sedemikian rupa agar peserta didik yang duduk berdampingan mengerjakan tes dengan kode paket perangkat tes yang berbeda. Waktu yang disediakan untuk mengerjakan tes 90 menit. Pelaksanaan uji- an melibatkan seluruh guru pengampu mata pelajaran fisika di setiap sekolah sebagai pengawas ujian.

Perangkat tes uji coba terdiri atas 4 paket soal. Selama pelaksanaan ujian keempat paket tes berkode A, B, C, dan D diujikan secara bersamaan di setiap kelas dan setiap peserta didik dalam satu kelas mendapat 1 paket tes untuk dikerjakan. Secara berturut-turut perangkat tes berkode A, B, C, dan D diujikan kepada 538, 508, 515, dan 454 responden.

Data respon peserta didik dalam penelitian ini diskor secara politomous dengan 4 kategori, yaitu kategori 4, 3, 2, dan 1. Kriteria pencapain setiap tingkat kategori bila memenuhi persyaratan sebagai berikut.

4: Dapat menyebutkan 3 pilihan pernyataan jawaban yang disediakan secara benar, dan menyebutkan jawaban lainnya yang belum disediakan yang dapat dikategorikan jawaban benar

3: Dapat menyebutkan 3 pilihan pernyataan jawaban yang disediakan secara benar, dan tidak atau menyebutkan jawaban lainnya yang belum disediakan yang dapat dikategorikan jawaban salah. Atau:

Dapat menyebutkan 2 pilihan pernyataan jawaban yang disediakan secara benar, dan menyebutkan jawaban lainnya yang belum disediakan yang dapat dikategorikan jawaban benar

2: Dapat menyebutkan 2 pilihan pernyataan jawaban yang disediakan secara benar, dan tidak atau menyebutkan jawaban lainnya yang belum disediakan yang dapat dikategorikan jawaban salah Atau:

Dapat menyebutkan 1 pilihan pernyataan jawaban yang disediakan secara benar, dan menyebutkan jawaban lainnya yang belum disediakan yang dapat dikategorikan jawaban benar

1: Dapat menyebutkan 1 pilihan pernyataan jawaban yang disediakan secara benar, dan tidak atau menyebutkan jawaban lainnya yang belum disediakan yang dapat dikategorikan jawaban salah Atau

Tidak menyebutkan pilihan tetapi dapat menyebutkan jawaban lainnya yang belum disediakan yang dapat dikategorikan jawaban benar

Data politomous 4 kategori dianalisis menurut Partial Credit Model (PCM). Hasil analisis kecocokan tes yang dilihat dari parameter INFIT untuk Mean Square (MNSQ) 
menunjukkan bahwa instrumen penilaian kinerja kemampuan inkuiri mata pelajaran fisika SMA memenuhi kriteria fit statistic menurut $P C M$ yang selengkapnya disajikan pada Tabel 5. Hasil analisis ke-93 butir tes memiliki nilai INFIT MNSQ antara 0,77 sampai dengan 1,3 yang artinya semua butir tes fit dengan PCM. Peta kecocokan butir tes dengan PCM disajikan pada Gambar 15.

Tabel 15. Parameter Fit Statistik Tes pada Level Peluang 0,50

\begin{tabular}{llcc}
\hline No. & Parameter tes & $\begin{array}{c}\text { Estimasi } \\
\text { butir }\end{array}$ & $\begin{array}{c}\text { Estimasi } \\
\text { case }\end{array}$ \\
\hline 1. & INFIT $M N S Q$ & $1,10 \pm 0,09$ & $1,11 \pm 0,08$ \\
2. & OUTFIT $M N S Q$ & $1,10 \pm 0,09$ & $1,10 \pm 0,12$ \\
3. & Difficulty rerata & \multicolumn{2}{c}{$0,0 \pm 0,24$} \\
\hline
\end{tabular}

Spesifikasi butir perangkat tes memiliki difficulty index di antara nilai $-0,83$ (item4) dengan kategori mudah sampai dengan $+0,84$ (item2) dengan kategori sedang. Difficulty index rata-rata sebesar $0,0 \pm 0,24$ dengan kategori sedang. Difficulty index ratarata aspek kemampuan inkuiri adalah subaspek perencanaan $=0,033$; subaspek pelaksanaan $=0,02$; dan subaspek pelaporan $=$ $-0,07$ yang secara rinci disajikan pada Tabel 16.

Berdasarkan hasil analisis butir juga diperoleh kurva hubungan antara ability dengan Total Information Function (TIF) dan Standard Error of Measurement (SEM). Gambar 4 menyajikan kurva Total Information
Function dan Standard Error of Measurement instrumen penilaian kinerja kemampuan inkuiri mata pelajaran fisika SMA. Berdasarkan kurva tersebut diketahui bahwa instrumen penilaian kinerja kemampuan inkuiri mata pelajaran fisika SMA lebih tepat diujikan pada responden dengan kemampuan antara -2,5 sampai dengan $+2,5$. Karena instrumen ini dapat memberikan informasi yang tinggi terhadap kemampuan inkuiri peserta didik dan tingkat kesalahan pengukuran yang rendah bila diujikan pada responden yang mempunyai kemampuan (ability) antara -2,5 sampai dengan $+2,5$.

Tabel 16. Difficulty Rerata Aspek/subaspek Kemampuan Inkuiri

\begin{tabular}{lc}
\hline Aspek/Subaspek Kemampuan Inkuiri & $\begin{array}{c}\text { Difficulty } \\
\text { Rerata }\end{array}$ \\
\hline PERENCANAAN & 0,033 \\
a. Merancang penyelidikan & 0,09 \\
b. Menyeleksi Prosedur & $-0,15$ \\
PELAKSANAAN & 0,02 \\
a. Melakukan Pengamatan & $-0,01$ \\
b. Merekam data/informasi & 0,03 \\
c. Mengikuti Intruksi & $-0,18$ \\
d. Melakukan Pengukuran & 0,14 \\
e. Memanipulasi Gerakan & $-0,13$ \\
f. Menimplementasikan prosedur/ & $-0,03$ \\
$\quad$ teknik/penggunaan peralatan & \\
g. Melaksanakan Penyelidikan & 0,23 \\
PELAPORAN & $-0,07$ \\
a. Membuat inferensi & $-0,11$ \\
b. Membuat Prediksi & $-0,24$ \\
c. Melaporkan hasil penyelidikan & 0,06 \\
d. Pengkomunikasian & 0,15 \\
\hline
\end{tabular}

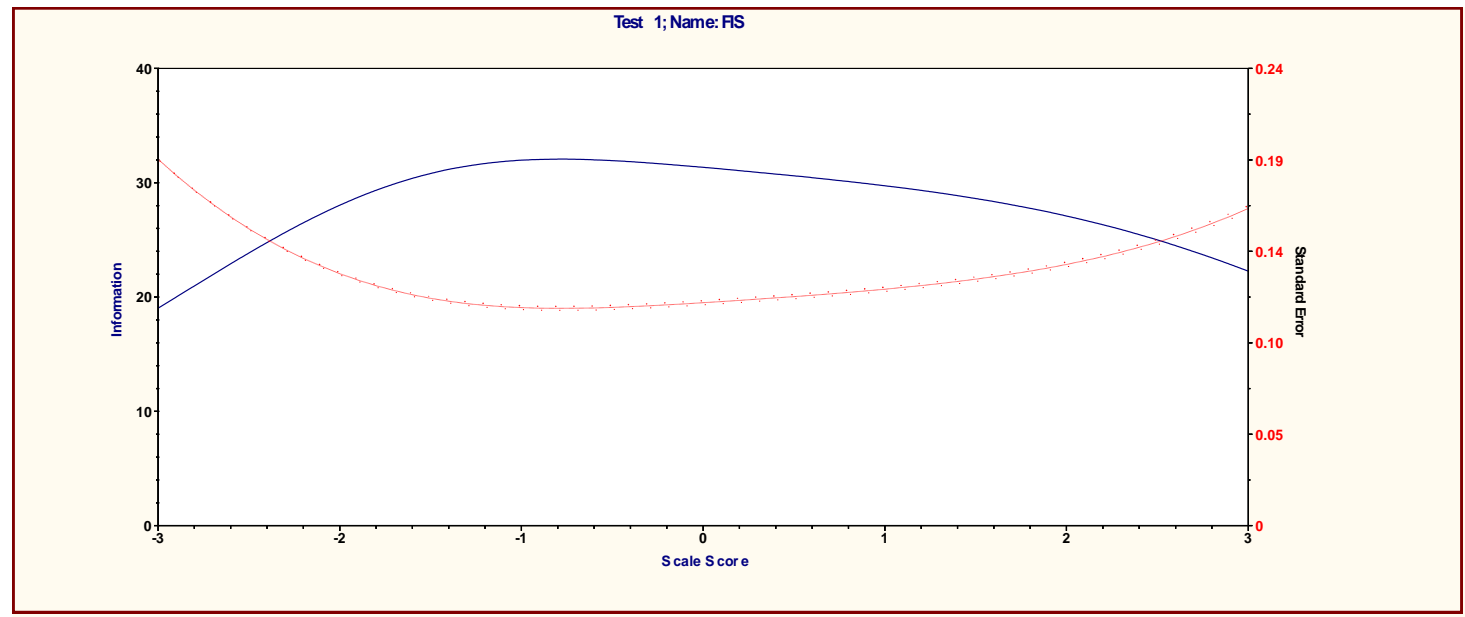

Gambar 4. Kurva TIF dan SEM Instrumen Tes Kemampuan Inkuiri mata pelajaran fisika SMA. 
QUEST: The Interactive Test Analysis system

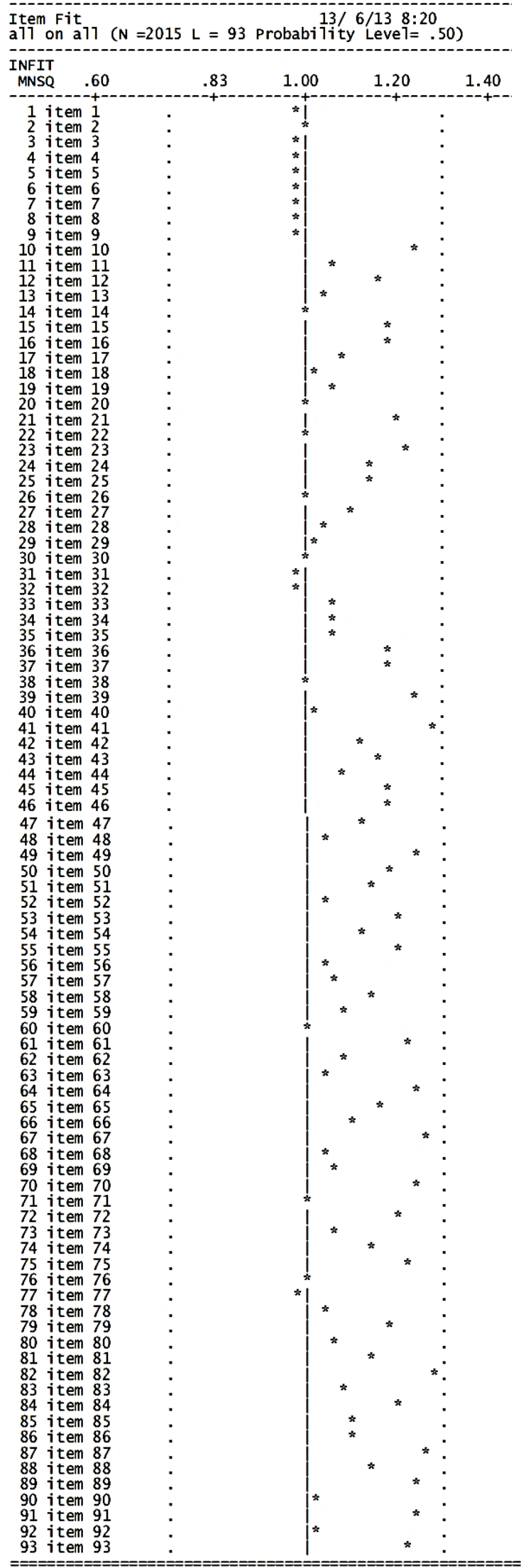

Gambar 5. Peta Kecocokan Butir dengan Model PCM.

\section{Hasil Pengukuran}

Pengukuran kinerja kemampuan inkuiri mata pelajaran fisika SMA diikuti oleh 2383 responden. Responden terdiri atas peserta didik kelas X sejumlah 1269 responden dan peserta didik kelas XI-IPA sejulah 1114 responden. Distribusi skor seluruh peserta didik di antara 0,1 sampai dengan 0,19 dalam skala logit antara -4 sampai dengan +4 . Gambar 6 menyajikan distribusi skor dan rata-rata hasil pengukuran kemampuan inkuiri mata pelajaran fisika SMA di lokasi pengukuran dalam skala logit sebesar 0,13 $\pm 0,015$. Artinya, peserta didik mempunyai kemampuan inkuiri di atas rata-rata.

Kemampuan inkuiri peserta didik dapat diestimasi menggunakan persentase rata-rata respon siswa menjawab benar pada setiap aspek dan subaspek yang diukur. Berdasarkan Tabel 17, diketahui bahwa respon siswa lebih dominan pada kategori 2 dan 3 dan hanya sebagian kecil persentase responden yang mampu mencapai kategori 4. Dengan kata lain, kemampuan inkuiri peserta didik masih ada yang belum memuaskan.

Tabel 17. Dominasi Respon Peserta Didik pada Setiap Aspek/Subaspek yang Diukur

\begin{tabular}{cc}
\hline $\begin{array}{c}\text { ASPEK/SUBASPEK KEMAMPUAN } \\
\text { INKUIRI }\end{array}$ & $\begin{array}{c}\text { Dominasi } \\
\text { Respon }\end{array}$ \\
\hline PERENCANAAN &
\end{tabular}

\begin{tabular}{ll} 
a. Merancang penyelidikan & Kategori 2 3 \\
b. Menyeleksi Prosedur & Kategori 3 \\
PELAKSANAAN & \\
$\begin{array}{l}\text { a. Melakukan Pengamatan } \\
\text { b. Merekam data/informasi } \\
\text { c. Mengikuti Intruksi }\end{array}$ & Kategori 2,3 \\
d. Melakukan Pengukuran & Kategori 2,3 \\
$\begin{array}{l}\text { e. Memanipulasi Gerakan } \\
\text { f. Mengimplementasikan prosedur/ } \\
\text { teknik/penggunaan peralatan }\end{array}$ & Kategori 3 \\
g. Melaksanakan Penyelidikan & Kategori 2 3 \\
PELAPORAN & Kategori 3 \\
a. Membuat inferensi & Kategori 2 3 \\
b. Membuat Prediksi & Kategori 2 \\
c. Melaporkan hasil penyelidikan & Kategori 3 \\
d. Pengkomunikasian hasil penyelidikan & Kategori 2,3 \\
\hline
\end{tabular}




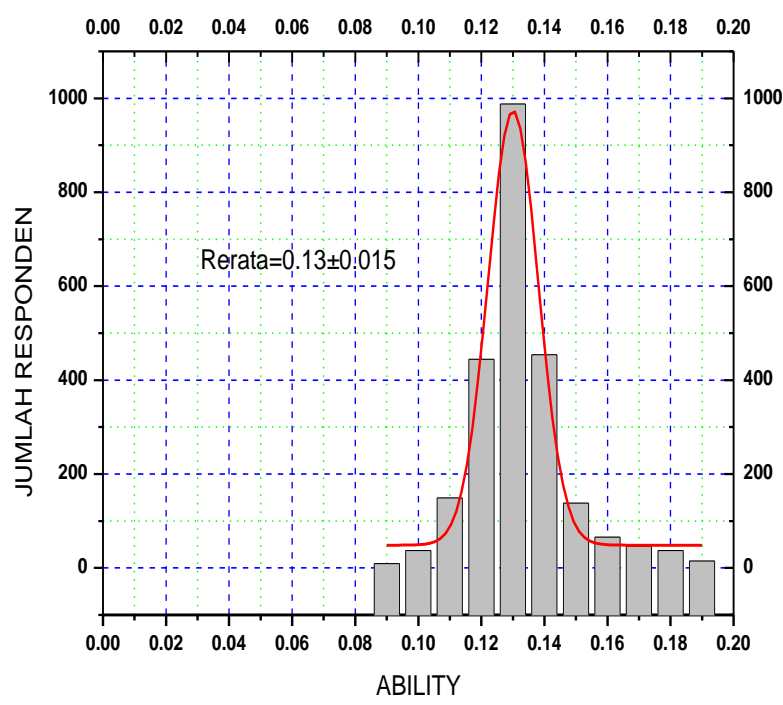

Gambar 6. Distribusi Skor Kemampuan Inkuiri Hasil Pengukuran.

Pembahasan

Perangkat penilaian kemampuan inkuiri mata pelajaran fisika SMA seluruhnya berjumlah 93 butir tes yang dibagi menjadi 4 paket perangkat tes, yakni perangkat tes 1 berkode A, tes II berkode B, tes III berkode C, dan tes IV berkode D. Setiap paket perangkat tes disusun berdasarkan pertimbangan keterwakilan setiap aspek dan subaspek kemampuan inkuiri yang akan diukur. Setiap paket perangkat tes terdiri atas 30 butir dengan 9 butir anchor termasuk di dalamnya. Jumlah butir anchor telah memenuhi jumlah minimal yang dipersyaratkan yaitu $20 \%$ dari total butir tes, dan masingmasing mewakili aspek yang diukur.

Instrumen penilaian kinerja kemampuan inkuiri mata pelajaran fisika SMA yang terdiri atas perangkat $\mathrm{A}, \mathrm{B}, \mathrm{C}$, dan $\mathrm{D}$ kesemuanya memenuhi kriteria valid. Validitas isi instrumen diperoleh melalui profesional judgement, dan validitas secara empiris dibuktikan dengan goodness of fit menurut patial credit model (PCM). Faktor-faktor pendukung sehingga instrumen yang dikembangkan memenuhi persyaratan validitas dapat diidentifikasi sebagai berikut. Pertama, butirbutir tes dikembangkan sesuai prosedur pengembangan instrumen penilaian. Kedua, butir tes dikembangkan dari indikator yang diturunkan dari setiap aspek yang diukur.
Ketiga, instrumen penilaian kinerja kemampuan inkuiri mata pelajaran fisika SMA telah divalidasi melalui profesional judgement dengan melibatkan sejumlah pakar pendidikan. Keempat, responden mengerjakan tes secara sungguh-sungguh di bawah pengawasan guru fisika di sekolahnya.

Fungsi informasi total tes relatif tinggi untuk kemampuan antara -2,5 sampai $+2,5$. Hal ini berarti bahwa instrumen yang dikembangkan juga memiliki reliabilitas yang tinggi karena tersusun dari butir-butir yang memiliki fungsi informasi yang tinggi dan butir-butir tes yang dikembangkan telah sesuai dengan kemampuan peserta didik yang diuji.

Index difficulty instrumen penilaian kinerja kemampuan inkuiri mata pelajaran fisika SMA yang dikembangkan pada penelitian ini bervariasi antara -2.0 sampai dengan $+2,0$, sehingga instrumen ini tergolong baik, karena telah memenuhi kriteria yang dipersyaratkan. Butir tes dengan indeks difficulty -2,0 dikategorikan butir sangat mudah, sedangkan indeks difficulty $+2,0$ dikategorikan butir sangat sulit. Dengan demikian, instrumen yang dikembangkan memenuhi persyaratan kategori baik.

Hasil pengukuran kemampuan inkuiri mata pelajaran fisika peserta didik SMA Negeri di DIY yang diikuti oleh 2383 responden menghasilkan distribusi skor antara 0.10 sampai dengan 0,19 dalam skala logit antara -4 sampai dengan +4 . Rata-rata hasil pengukuran kemampuan inkuiri mata pelajaran fisika SMA sebesar 0,13 $\pm 0,015$. Berdasarkan skor rata-rata kinerja kemampuan inkuiri mata pelajaran fisika peserta didik SMA di DIY diketahui bahwa peserta didik mempunyai kemampuan inkuiri di atas rata-rata.

Kemampuan inkuiri peserta didik yang diestimasi menggunakan persentase rata-rata respon siswa menjawab benar pada setiap aspek dan subaspek yang diukur dapat diketahui bahwa respon siswa dominan pada kategori 2 dan 3 dan hanya sebagian kecil persentase responden yang mampu mencapai kategori 4. Keadaan ini mengindikasikan bahwa peserta didik SMA sebagian 
besar te-lah memiliki kemampuan inkuiri di atas rata-rata.

\section{Simpulan dan Saran}

Simpulan

Perangkat tes penilaian kinerja kemampuan inkuiri yang dikembangkan pada kemampuan perencanaan, pelaksanaan, dan pelaporan terdiri atas perangkat tes $\mathrm{A}, \mathrm{B}, \mathrm{C}$, dan $\mathrm{D}$ yang setiap terdapat 30 butir soal dengan 9 anchor items.

Perangkat tes penilaian kinerja kemampuan inkuiri telah memenuhi validitas isi dengan expert judgement dan telah mendapatkan bukti empiris fit dengan partial credit model (PCM) berdasarkan data politomus empat kategori.

Seluruh butir soal pada perangkat tes penilaian kemampuan inkuiri dalam kriteria baik karena tingkat kesulitannya masih pada rentang antara -2,0 sampai dengan 2,0. Tingkat kesulitan tes paling sulit adalah butir-butir aspek kemampuan merencanakan, kemudian disusul aspek melaksanakan, dan pelaporan hasil penyelidikan.

Berdasarkan fungsi informasi total, perangkat tes penilaian kinerja kemampuan inkuiri mata pelajaran fisika SMA sangat tepat digunakan untuk mengukur peserta didik yang berkemampuan antara -2,5 sampai dengan 2,5. Perangkat tes penilaian kinerja kemampuan inkuiri dapat digunakan untuk mengukur kemampuan inkuiri peserta didik menurut partial credit model berdasar pada data politomus empat kategori.

Profil kemampuan inkuiri peserta didik pada mata pelajaran fisika SMA memiliki distribusi skor antara 0,10 sampai dengan 0,19 dengan rata-rata $0,13 \pm 0.148$ dari skala logit (log odds unit) antara +4 sampai dengan -4. Skor yang dicapai peserta didik sudah berada di atas kemampuan ratarata, dan berada pada kriteria tinggi.

Profil kemampuan inkuiri peserta didik pada mata pelajaran fisika SMA pada aspek-aspek perencanaan, pelaksanaan, dan pelaporan dominan pada kategori-2 dan kategori-3 dari kategori-1 hingga kategori-4.
Artinya, kemampuan inkuiri mata pelajaran fisika SMA siswa berada di atas rata-rata.

Saran

Para guru fisika SMA hendaknya melakukan penilaian kemampuan inkuiri secara periodik di sekolahnya agar perkembangan kemampuan inkuiri peserta didik terukur. Bagi Dinas Pedidikan, perlu dilakukan pelatihan penyusunan instrumen penilaian kinerja kemampuan inkuiri mata pelajaran fisika bagi para guru. Peneliti lain dapat melakukan penelitian lebih lanjut agar kemampuan inkuiri peserta didik pada mata pelajaran fisika SMA dapat didiskripsikan secara komprehensip dengan responden yang meliputi SMA negeri dan Swasta.

\section{Daftar Pustaka}

Adams, R.J \& Khoo, Siek-Toon. (1996). Quest: The interactive test analysis system version 2.1. camberwell, Victoria: The Australian Council for Educational Research.

Bryce, T.G.K, McCall, J., Mac Groger, J., Robertson, I.J. and Weston, R.A.J. (1990). Techniques for assessing process skill in practical science: teacher's guide. Oxford: Heinemann Educational Books.

Chiappetta, E.L. \& Koballa, T.R (2010). Science instruction in the middle and secondary schools $7^{\text {rd }}$ ed. Pearson Education.Inc.

Depdikbud. (2014). Peraturan Menteri Pendidikan dan kebudayaan No. 104 Th 2014 Tentang Penilaian hasil belajar oleh pendidik pada pendidikan dasar dan pendidikan menengah.

Glencoe Science. Performance assessment in the classroom. Glencoe McGwaw-Hill.New York

Hambleton, R.K. \& Swaminathan, H. (1985). Item response theory. Boston: KluwerNijhoff Publishing. 
Mardapi, D. (2012). Pengukuran, penilaian, dan evaluasi pendidikan. Yogyakarta: Nuha Litera.

Moyer, R.H, Hackett, J.K, \& Everett, S.A. (2007). Teaching science as investigations modeling inquiry through learning cycle lessons. New Jersey: Pearson, Merrill Prentice Hall.

Oriondo, L.L. \& Dallo-Antonio. (1998). Evaluating educational outcomes (test, measurement, and evaluation), (5 $5^{\text {th }} \mathrm{ed}$.). Queson City: REX Printing Company, Inc.

Rezba, R.J, Sparague, C.S., Fiel, R.L, Fuck, H.J., Okey, J.R., \& Jaus, H.H. (1995). Learning and assessing science process skill. $3^{\text {td }}$ ed. Iowa: Kendall/Hunt Publishing Company.

Ruiz-Primo, M.A. \& Shavelson, R.J. (1996). Rhetoric and Reality in science performance assessment: an update. Journal of reseach and science teaching, Vol.33

Subali, B. (2009). Pengembangan tes pengukur keterampilan proses sains pola divergen mata pelajaran biologi SMA. Prosiding Seminar Nasional Biologi, Lingkungan dan Pembelajaran, jurdik Biologi, FMIPA UNY, 4 Juli 2009, 581-593.

Wenning, C.J. (2005). Implementing inquiry-based instruction in the science classroom. A new model for solving the improvement of practice problem. J. Phys. Tchr. Educ. Online 2(4), May 2005.

Wenning, C.J. (2005). Levels of inquiry: Hierarchies of pedagogical practices and inquiry processes. JPTEO, J. Phys. Tchr. Educ. Online 2(3), February 2005. 